\title{
OPTIMIZING THE COMPETITIVENESS OF RETURN ON MUDHÂRABAH TIME DEPOSIT IN IMPROVING PUBLIC INTEREST TO INVEST IN ISLAMIC BANK
}

\author{
Syaparuddin \\ State College for Islamic Studies of Watampone \\ (safarb135@gmail.com)
}

\begin{abstract}
The aim of this study is to explain the calculation of return on mudhârabah time deposit for the depositors of Islamic banks, and the provision of a fair return to the depositors without leaving any shariah elements. These two issues have become urgent to be discussed in this study, because if their money is deposited in Islamic banks, it will increase the amount of funds available in the Islamic bank, and the amount of funds available directly influence the size of the investment return on Islamic banks. If the results of the large investment, the returns will be obtained by the depositors are also large, and vice versa. In addition, it will also create a sense of calm and peace for themselves, because the money they have deposited in Islamic bank is not only quaranteed by the gorverment but also the system is run in accordance with the shariah of Islam.
\end{abstract}

Tulisan ini bertujuan untuk menjelaskan perhitungan return deposito mudhârabah bagi deposan di bank syariah, dan pemberian return tersebut secara adil kepada deposan tanpa meninggalkan unsur kesyariahannya. Dua permasalahan ini menjadi urgen untuk dibahas dalam tulisan ini, karena jika uang mereka didepositokan di bank syariah akan meningkatkan jumlah dana yang tersedia di bank syariah tersebut, dan jumlah dana yang tersedia tersebut berpengaruh langsung terhadap besar kecilnya hasil investasi bank syariah. Jika hasil investasi tersebut besar, maka return yang akan diperoleh para deposan juga besar, demikian pula sebaliknya. Selain itu, juga akan menciptakan rasa tenang dan tentram bagi mereka sendiri, karena keberadaan uang mereka tidak saja dijamin oleh pemerintah tetapi juga sistemnya dijalankan sesuai dengan syariat Islam.

Keywords: Islamic Bank, Mudhârabah, Time Deposit, Depositor, Return. 


\section{A. Introduction}

Investment is a muamalah activity highly recommended in Islam, because by investing assets held to be productive and bring benefits to the economy and society at large. Investment can be simply defined as activities aimed at developing the wealth and closely related to the future. ${ }^{1}$ Thus, the investment is as a means for humans to maintain the existence of their life when he was weak and helpless. By investing, people will feel a little safer when he was ill, infirm, elderly, or losing a job because they still have something that can be used for treatment, meals, school fees, tuition of their children, and others.

Islamic impetus to investment activities can be understood from the Koran ban on the activity of hoarding money and property held as mentioned in the Q.S. 9: $34 .^{2}$ This verse indicated that the money they have had to be rotated in the economy in order to generate returns for their owners and beneficial to others. Therefore, all the money owned supposed to be invested in the productive sector profitable. Prophet did not agree to let unproductive capital resources by saying: "Give me a chance to those who have land to use it, in his own way, and if not done, let it be given also others to use it" (Naratted by Muslim). Besides the Caliph Umar emphasized that muslims should use their capital productively by saying: those who have money need invest, and those who have need to use land. ${ }^{3}$

Currently many Islamic financial products that can be selected as a means of investment, for example, choosing Islamic banks as fund parking lot. Islamic banks provide an Islamic investment instrument in the form of mudhârabah time deposit. Wiroso said that mudhârabah time deposit is a time deposit product that is based on the principle of mudhârabah muthlaqah, where the owner of the funds gives full freedom to the bank to manage the investment and the results or profits from the management of the fund will be obtained according to an agreed ratio before. ${ }^{4}$ Mudhârabah time deposit is an investment through third party deposit (company or corporation) that may only be withdrawn within a certain period (maturity) to get profit-sharing. ${ }^{5}$

${ }^{1}$ Charles P. Jones, Investments: Analysis and Management (New York: John Wiley \& Sons Inc., 1996), p. 6.

${ }^{2}$ Departemen Agama RI, Al-Qur'an dan Terjemahnya (Bandung: CV Penerbit Diponegoro, 2003), p. 153.

${ }^{3}$ Nur Kholis, dkk., Pengantar Ekonomi Islam (Yogyakarta: Kopertais Wilayah III UIN Sunan Kalijaga Yogyakarta, 2012), p. 177.

${ }^{4}$ Wiroso, Penghimpunan Dana dan Distribusi Hasil Usaha Bank Syariah (Jakarta: Grasindo, 2005), p. 57.

${ }^{5}$ Undang-Undang Republik Indonesia No. 21 Tahun 2008 tentang Perbankan Syariah pada Bab I Pasal 1 Ayat 22. 
This type of third party fund is more and more increasingly demanded by the public. It can be seen for its composition in the Islamic banks (Islamic Commercial banks and Islamic business units), wherein its composition continues to increase high enough each year (2010-2014). ${ }^{6}$ The composition of mudhârabah time deposit in Indonesia Islamic banks can be presented in the following table:

Table 1: Composition of Mudhârabah Time Deposits in Indonesia Islamic Banks

\begin{tabular}{|l|l|lllll|}
\hline No & \multicolumn{1}{|c|}{$\begin{array}{c}\text { Type of } \\
\text { Bank/Currency }\end{array}$} & $\begin{array}{c}\text { Composition of Mudharabah Time Deposits } \\
\text { (Billion Rp.), Year: 2010-2014 }\end{array}$ \\
\hline 1 & $\begin{array}{l}\text { Islamic Commercial } \\
\text { Banks }\end{array}$ & 2010 & 2011 & 2012 & 2013 & 2014 \\
& $\begin{array}{l}\text {-Rupiah } \\
\text {-Roreign Exchange }\end{array}$ & 42.206 & 67.942 & 80.576 & 100.105 & 123.524 \\
\hline 2 & $\begin{array}{l}\text {-Flamic } \quad \text { Business } \\
\text { Islamits }\end{array}$ & 2010 & 2011 & 2012 & 2013 & 2014 \\
& $\begin{array}{l}\text { Units } \\
\text {-Rupiah }\end{array}$ & 6.856 & 10.875 & 16.828 & 22.869 & 26.242 \\
\hline & -Foreign Exchange & 35 & 165 & 1.300 & 2.056 & 1.868 \\
\hline
\end{tabular}

Source: Indonesia Financial Services Authority (November 2014), after being reprocessed

The table above shows that the public interest in depositing their money in the form of rupiahs and foreign exchange in Islamic banks has increased from year to year, and the increase is much higher than the increase in conventional banks. However, the composition of deposits in conventional banks is much greater than the composition of mudhârabah time deposit in Islamic banks. ${ }^{7}$ It means that people are still more dominant depositing their money in conventional banks than depositing their money in Islamic banks. This can be presented in the following table:

\section{Tabel 2: Composition of Time Deposits in Indonesian Convensional Banks}

\begin{tabular}{|l|l|lll|}
\hline No & Type of Bank/Currency & \multicolumn{2}{l}{$\begin{array}{l}\text { Composition of Time Deposits (Billion } \\
\text { Rp.) } \\
\text { Year: 2012-2014 }\end{array}$} \\
\hline \multirow{2}{*}{1} & Commercial Banks & 2012 & 2013 & 2014 \\
\cline { 2 - 5 } & -Rupiah & 1.179 .242 & 1.331 .527 & 1.623 .140 \\
\hline
\end{tabular}

${ }^{6}$ Indonesia Financial Services Authority (OJK), Indonesia Banking Statistics, Montly Journal (ISSN: 2086-2954), Vol. 12 No. 12 November 2014, p. 72-73.

${ }^{7}$ Ibid., p. 13-19. 


\begin{tabular}{|c|c|c|c|c|}
\hline & -Foreign Exchange & 202.056 & 272.952 & 281.448 \\
\hline \multirow[t]{3}{*}{2} & State Owned Banks & 2012 & 2013 & 2014 \\
\hline & -Rupiah & 378.829 & 420.785 & 540.650 \\
\hline & -Foreign Exchange & 67.283 & 86.903 & 73.640 \\
\hline \multirow[t]{4}{*}{3} & Foreign Exchange & 2012 & 2013 & 2014 \\
\hline & Commercial Banks & & & \\
\hline & -Rupiah & 541.95 & 629.323 & 720.457 \\
\hline & -Foreign Exchange & 85.179 & 126.018 & 161.134 \\
\hline \multirow[t]{3}{*}{4} & $\begin{array}{l}\text { Non-Foreign Exchange } \\
\text { Commercial Banks }\end{array}$ & 2012 & 2013 & 2014 \\
\hline & -Rupiah & 86.478 & 102.636 & 114.580 \\
\hline & -Foreign Exchange & 0 & 0 & 0 \\
\hline \multirow[t]{3}{*}{5} & $\begin{array}{ll}\text { Regional Development } \\
\text { Banks }\end{array}$ & 2012 & 2013 & 2014 \\
\hline & -Rupiah & 84.903 & 83.838 & 149.731 \\
\hline & -Foreign Exchange & 711 & 974 & 1.137 \\
\hline \multirow[t]{3}{*}{6} & Joint Venture Banks & 2012 & 2013 & 2014 \\
\hline & -Rupiah & 47.948 & 53.835 & 55.097 \\
\hline & -Foreign Exchange & 30.706 & 43.160 & 30.067 \\
\hline \multirow[t]{3}{*}{7} & Foreign Owned Banks & 2012 & 2013 & 2014 \\
\hline & -Rupiah & 39.133 & 41.111 & 42.625 \\
\hline & -Foreign Exchange & 18.176 & 15.897 & 15.470 \\
\hline
\end{tabular}

Source: Indonesia Financial Services Authority (November 2014), after being reprocessed

The table above shows that people are more likely to choose the conventional banks than Islamic banks to deposit their money. The cause is the return of deposits offered by conventional banks is certain, namely in the form of fixed interest and almost no risk. In fact, if interest rates rise, the return that would be obtained by depositors will also be greater. Increasing interest rates may lead to intense competition between Islamic banks and conventional banks in attracting and retaining the loyalty of their customers. ${ }^{8}$ Therefore, Islamic banks should be able to optimize the competitiveness of return on deposits are offered to the public. In addition, Islamic banks also need to educate them to understand the advantages, that competitiveness is that it offers not only from the aspect of profit but also from the aspect of non-profit in order to create economic justice in their midst. However this is not optimal.

${ }^{8}$ Adiwarman A. Karim, Bank Islam: Analisis Fiqih dan Keuangan (Jakarta: RajaGrafindo, 2007), p. 339. 
Based on the explanation above, the issues raised in this paper are: (1) How is the return on mudharabah time deposit calculated for depositors of Islamic banks, and (2) Can mudhârabah time deposit provide a fair return to depositors without leaving the elements of its shariah, so that people will be interested in investing in Islamic banks. These two issues have become urgent to be discussed in this paper, because if they deposit their money in Islamic banks, they will increase the amount of funds available in the Islamic bank, and the amount of available funds is a direct effect on the size of the investment return of Islamic banks. If the results of the large investment, the returns will be obtained by the depositors are also large, and vice versa. In addition, it will also create a sense of calm and peace for themselves, because their money is not only guaranteed by the government but also the system is run in accordance with the sharia of Islam.

\section{B. Defenition dan Legitimacy of Mudhârabah Time Deposit}

One of funding products offered by Islamic banks to customers is time deposit. Time deposit can be useful to meet the needs of the community (customers) who have a shortage of liquidity, and could also serve as a saving and as a fairly promising investment instrument as well. According to Law No. 10 of 1998, time deposit is a deposit that can be withdrawn only at a specific time based on an agreement with the bank depositors. ${ }^{9}$ Namely, withdrawal time has been determined (fixed time) adjusted by agreement between the depositors and the bank at the opening of concerned deposit. The allocation and usefulness of time deposit is more stressed as an investment instrument than as an instrument for excess liquidity. ${ }^{10}$

In contrast to conventional bank which provides return in the form of interest for its depositors, then the return provided by Islamic bank for its depositors is in the form of profit-sharing as for ratio agreed at the beginning of the transaction. Therefore, the shariah deposit (Islamic time deposit) is based on the principles of mudhârabah contract, which is associated with the storage destination of funds in the form of time deposit to invest excess liquidity. ${ }^{11}$

It is expressed in the fatwa of DSN ${ }^{12}-\mathrm{MUI}^{13}$ No. 03/DSN-MUI/IV/2000 on time deposit. In the fatwa stated that if it refers to the practice of the deposits

\footnotetext{
${ }^{9}$ Veithzal Rivai, dkk., Bank and Financial Management (Jakarta: RajaGrafindo, 2007), p. 412.

${ }^{10}$ Rahmadi Usman, Produk dan Akad Perbankan Syariah di Indonesia (Bandung: Citra Aditya Bakti, 2005), p. 162.

${ }^{11}$ Saad Abdul Sattar Al-Harram, Islamic Finance: Partnership Financing (Malaysia: Pelanduk Publications, 1996), p. 55.

${ }^{12}$ Nasional Shariah Council (Dewan Syariah Nasional).

${ }^{13}$ Indonesian Ulama Council (Majelis Ulama Indonesia).
} 
found in conventional banking, banking services in the form of deposits is not in accordance with shariah because there are elements of interest (riba) in it. It required a deposit services in accordance with shariah and does not reduce the feature that has been inherent in it for easy human affairs in a financial transaction. Based on this, deposit products allowed by DSN (National Shariah Counsil of MUI) is a time deposit based on the principles of mudharabah, known as mudhârabah time deposit. Mudhârabah time deposit is a kind of deposit where the depositor (shahib al-mâl) entrusts his funds managed by the bank (mudhârib) and the profits made are shared between the two parties according to a mutually agrred ration at the beginning of the transaction. It uses the principles of mudhârabah muthlaqah, because the management of funds is on the responsibility of mudharib (bank) fully. ${ }^{14}$ It means that in mudhârabah time deposit, the investment activities are not bound by any third party relating to Islamic banks.

The general rules on mudhârabah time deposit according the fatwa of DSN-MUI, namely: (1) In this transaction the customer acts as a shahib al-mâl, or fund owner, and the bank acts as mudharib or fund manager, (2) In its capacity as mudhârib, bank can perform a variety of kind of business that does not conflict with Islamic principles and develop it, including doing mudharabah with other parties, (3) Capital must be stated with the amount, in cash and no debt, (4) Profit-sharing must be expressed in the form of ratio and poured in the contract when opening a time deposit account, (5) The bank as mudhârib covers operational costs by using its profit ratio (6) The bank is not allowed to reduce customor's profit ratio without his agreement. ${ }^{15}$

Based on the general rules as mentioned above, the withdrawals of mudhârabah time deposit can only be done at certain times based on an agreement between the fund owner (shahib al-mâl) with the bank (mudhârib) as a fund manager. The profit made must be shared in accordance with an agreed ratio, but the bank as mudhârib does not guarantee customer's funds unless there is annother regulation for it in the applicable legislation. The Islamic bank can perform a wide variety of businesses that do not conflict with the Islamic principles and develop it, including doing mudhârabah with third parties. The Islamic bank as mudhârib has properties as a trustee, which must be careful or prudent and also acts in good faith and gets responsible for everything that arises from fault or negligence. In addition, The Islamic bank also acts as the authority of fund owner's business that are expected to gain an optimal profit as possible without violating the rules of shariah.

\footnotetext{
${ }^{14}$ Adiwarman A. Karim, Bank Islam, p. 303-304.

${ }^{15}$ Dewan Syariah Nasional MUI, Fatwa DSN-MUI tentang Deposito, No.: 03/DSN-MUI/IV/2000.
} 


\section{Scheme of Mudhârabah Time Deposit in Islamic Bank}

There are three types of flow schemes for customer's funds to the Islamic banks with the principles of mudhârabah which are likely to use. Adiwarman Karim explained that the three flow schemes of customer's funds to the Islamic bank with the principles of mudhârabah are mudhârabah muqayyadah off balance sheet, mudhârabah muqayyadah on balance sheet, and mudhârabah muthlaqah on balance sheet. ${ }^{16}$ The Islamic banks, according to the writer's observation, do not apply the three schemes simultaneously, but they have to adjust to the conditions and circumstances that occurred in the community. If the scheme of mudhârabah muqayyadah off balance sheet is used by the Islamic banks, the flow of funds will derive from one investor customer to financing customer. The Islamic banks just simply acts as an intermediary (arranger) in bringing together between the investor customer and the financing customer. The recording of transaction in the Islamic bank is carried off balance sheet. The profit is only shared between the investor customer and the financing customer. The magnitude of the profit-sharing depends on the agreement between the investor customer and the financing customer, the Islamic bank only earns a commission (arrange fee). It is called mudhârabah because it uses profit-sharing scheme, and called muqayyadah because there are restrictions to use in it, ie only for the implementation of certain businesses, and off balance sheet because it is not recorded in the balance sheet of Islamic bank. ${ }^{17}$ The characteristics of this type of fund flow are (1) as a proof of deposit, the bank will publish a special deposit evidence. The Islamic bank is required to separate funds from other accounts. This special deposit is recorded on a separate heading in the accounts of the administration, (2) a special deposit fund should be distributed directly to the customer mandated by the investor, and (3) the Islamic bank receives commissions (fees) for services to bring the two parties, while profit-sharing ratio are only applicable for the investor and the financing customer. ${ }^{18}$

The flow scheme for customer's fund to the Islamic bank with the principles of mudhârabah muqayyadah off balance sheet, can be presented in the figure below:

${ }^{16}$ Adiwarman A. Karim, Bank Islam, p. 312.

${ }^{17}$ Ibid.

${ }^{18}$ Ascarya, Akad dan Produk Bank Syariah (Jakarta: RajaGrafindo, 2007), p. 119. 
Figure 1: Scheme of mudhârabah muqayyadah off balance sheet

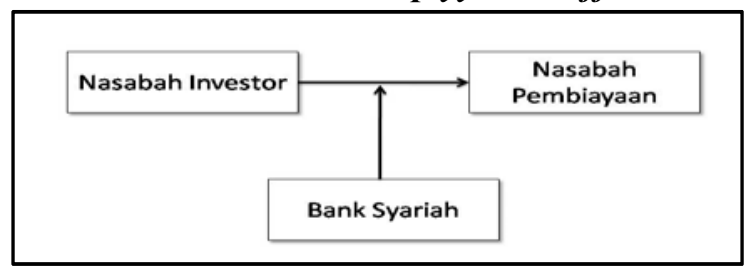

Source: Adiwarman Karim (2007: 312), after being reprocessed

If the scheme of mudhârabah muqayyadah on balance sheet are used by Islamic banks, the flow of funds from the invetor customer to the Islamic bank forms a special deposit (restricted investment), where the invetor customer can set certain requirements that must be complied with by the Islamic bank. For example required to be used on a particular business, or required to be used with a particular contract, or required to be used on a particular customer. ${ }^{19}$ The characteristics of this fund flow are (1) The fund owner is required to establish certain requirements that must be followed by the Islamic bank which is required to prepare a contract that arranges requirements for the distribution of special deposit fund, (2) The Islamic bank is required to notify the fund owner about the ratio and the procedures for profit notification and the sharing of return or risk that may result from the storage of the fund. If the agreement has been reached, it should be included in the contract, (3) As proof of the deposit bank will publish special deposit evidence. The Islamic bank is required to separate the fund from other accounts, and (4) The Islamic bank is required to provide a certificate or mark of storage (slips) deposit to the depositor for his mudhârabah time deposit. ${ }^{20}$

The flow scheme for customer's fund to Islamic bank with the principle of mudhârabah muqayyadah on balance sheet, can be presented in the figure below:

Figure 2: Scheme of mudhârabah muqayyadah on balance sheet

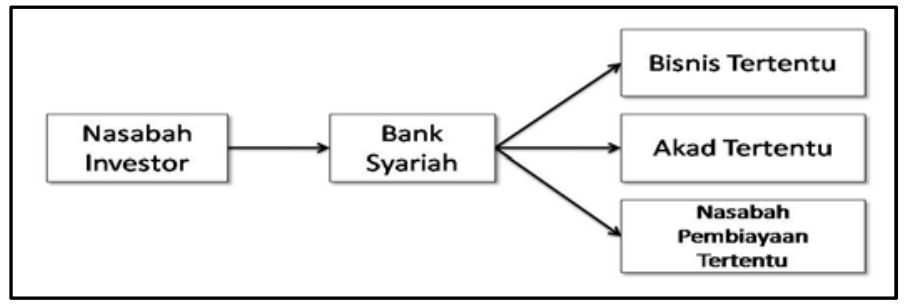

Source: Adiwarman Karim (2007: 314), after being reprocessed

\footnotetext{
${ }^{19}$ Adiwarman A. Karim, Bank Islam, p. 314.

${ }^{20}$ Ascarya, Akad dan Produk Bank Syariah, p. 119.
} 
If the scheme of mudhârabah muthlaqah on balance sheet are used by the Islamic bank, then the entire flow of funds to the investor customer of the Islamic bank should not be contained certain restrictions on business execution financed and contract used. In other words, the Islamic bank has the right and full freedom in managing and investing investor customer's fund into various business sectors that are expected to earn a profit. This flow of fund can be a saving and deposit, in the form of mudhârabah saving and mudhârabah time deposit. ${ }^{21}$

The general rules for these products are (1) The Islamic Bank is required to notify the fund owner about the ratios and procedures for notification or profit and risk sharing that may result from the storage of funds. If the agreement has been reached, it must be included in the contract. (2) For mudhârabah saving, the Islamic bank can provide a saving book as proof of storage, as well as ATM card or other tool withdrawal to the saver. For mudhârabah time deposit, the Islamic bank is required to provide a certificate or mark of storage (slips) deposit to the depositor, (3) Mudhârabah saving can be taken at any time by the saver in accordance with the agreed treaty, but is not allowed to run into a negative balance, (4) Mudhârabah time deposit can only be disbursed in accordance with the agreed time period. Deposits were extended after the due date, will be treated the same as a new deposit, but when the contract has been included automatic renewal, a new contract is not need to be made, and (5) The other rules relating to saving and time deposit remain valid as long as not contrary to Islamic principles. ${ }^{22}$

The flow scheme for customer's fund to the Islamic bank with the principle of mudhârabah muthlaqah on balance sheet, can be presented in the figure below:

\section{Figure 3: Scheme of mudhârabah muthlaqah on balance sheet}

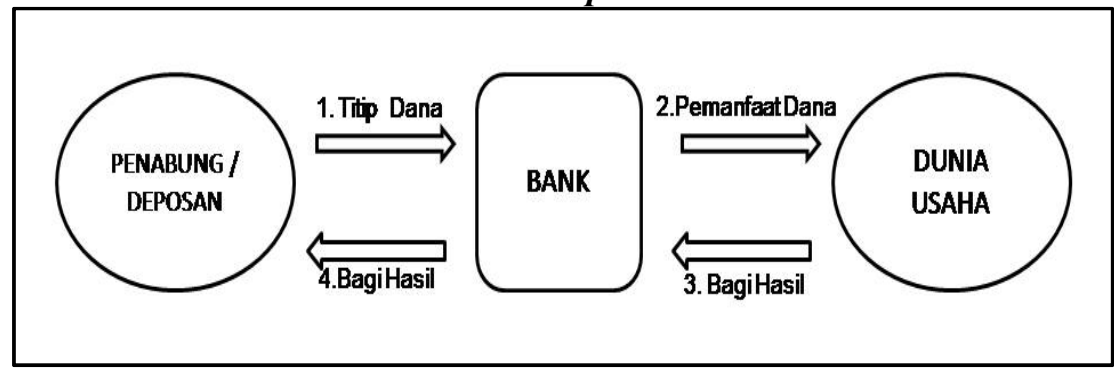

Source: Adiwarman Karim (2007: 315), after being reprocessed

${ }^{21}$ Adiwarman A. Karim, Bank Islam, p. 317.

${ }^{22}$ Wiroso, Penghimpunan Dana dan Distribusi Hasil Usaha Bank Syariah, p.

56. 
Generally in practice, the Islamic banks in Indonesia to use this type of scheme in offering mudhârabah time deposit to the public. From the above scheme can be explained that the Islamic bank that received funds in the form of time deposits from the public with the principles of mudharabah muthlaqah on balance sheet, will share profits togther with the customers with specific agreements that have been approved, where the Islamic bank acts as mudharib (fund managers), while the customer acts as a shahib al-mâl (fund owner). In the capacity as mudhârib, the Islamic bank will perform a wide variety of businesses that are not contrary to the Islamic principles and develop it, including doing mudhârabah with third parties. Thus, the Islamic bank as mudhârib has properties as trustee, which must act carefully or wise and act in good faith and get responsible for everything that arises from fault or negligence. In addition, the Islamic bank also acts as the auth of the authority for fund owner's business that is expected to gain an optimal profit as possible without violating the rules of shariah.

\section{Calculation of Return on Mudhârabah Time Deposito}

The amount of payment for profit-sharing to the investor customer of the Islamic bank relies heavily on income earned by the Islamic bank as mudhârib on the mudhârabah fund management. If the result of operations of the Islamic bank to obtain is large, the distribution of the result of operations is also large, otherwise if the Islamic bank obtains a small result, the distribution of profit-sharing to the customer is also small. This concept according to Muhammad, has an element of justice, there is no injured party but all parties benefit. $^{23}$ The gain obtained by the investor customer is dependent upon the ability of bank to invest funds entrusted to it. Following this, the author will present how to set ratio and return for the profit-sharing of mudhârabah time deposits and illustrate the comparison with the system of interest.

\section{Determination of Profit-Sharing Ratio}

The term used in the Islamic bank to share profit with the customer is the profit-sharing ratio, ie the proportion of profit-sharing between the customer and the Islamic bank. ${ }^{24}$ For example, if the customer service of Islamic bank offers profit-sharing ratio of time deposit amounted to 65:35, it means that the customer of Islamic bank will acquire a $65 \%$ profit-sharing of the investment returns generated by the Islamic bank through the management of public funds

\footnotetext{
${ }^{23}$ Muhammad, Manajemen Bank Syariah: Edisi Revisi (Yogyakart: UPP AMP YKPN, 2005), p. 115.

${ }^{24}$ Albertus Lalaun, Analisis Perhitungan Bagi Hasil yang Diterima oleh Nasabah pada PT. Bank Muamalah Cabang Ambon, Jurnal Sosial Keagamaan Inferensi, Vol. 8 No.2 Desember 2014, p. 441.
} 
in the real sector, while the Islamic bank will get a portion of the profit-sharing of $35 \%$. How to calculate the profit-sharing ratio of time deposit?

Prior to the calculation of the profit-sharing ratio done, first thing to do is to know the factors that affect the determination of the profit-sharing ratio of time deposit. The factors that influence it, namely: the type of deposit products, investment income and the estimated operational costs of bank. After that calculating the level of investment income that can be distributed to customers. The expectation of investment income is calculated by the Islamic bank to see the performance of economic activity in sectors that would like to invest, for example in the property sector, trade, agriculture, telecommunications or transportation sectors. Every economic sector has different characteristics and performance, so it will provide investment returns that differ as well. As befits an investment manager, the Islamic bank will use a variety of economic and financial indicators that can reflect the performance of the sector to calculate the expected/projected return on investment. Including historical indicators (track record) from investing activities of the Islamic bank that have been done, as reflected in the average value of all types of Islamic bank financing that has been granted to the real sector. ${ }^{25}$ From the results of these calculations, the amount of investment revenue that can be obtained in the form of equivalent rate that will be distributed to customers, is for example $11 \%$.

Further calculating the amount of investment income to cover part of the Islamic bank in operational costs, and also provide a reasonable income. The amount of operating costs depending on the level of efficiency of each bank. Meanwhile, a reasonable amount of income, among others, refers to financial indicators of the concerned Islamic bank as ROA (Return on Assets) and other relevant indicators. For example the calculation results obtained that the Islamic bank needs investment income calculated in equivalent rate- -which amounted to $6 \%$. The calculation of equivalent rate is done after knowing the portion of revenue for the fund owner (PSKD). The formula used to calculate the return of income for fund owner (RHPD) or better known as revenue sharing level (equivalent rate) for each group of funds can be presented as follows: ${ }^{26}$

$$
\mathbf{E R}=\frac{\mathrm{PHPD}}{\mathrm{SRKD}} \times \frac{365}{\mathrm{HBH}} \quad \mathrm{X} 100 \%
$$

Short description:

ER : Equivalen Rate

PHPD : Income portion for fund owner

SRKD : Avarage daily balance for type of fund group

\footnotetext{
${ }^{25}$ Muhammad, Manajemen Bank Syariah, p. 110-111.

${ }^{26}$ Ibid.
} 
HBH : Day of profit-sharing

From the two numbers (customer: $11 \%$, Islamic bank: $6 \%$ ), the profitsharing ratio can be calculated. The profit-sharing portion for customer is as follows: $[11 \%$ divided by $(11 \%+6 \%)]=0.65$ or $65 \%$, and for Islamic bank amounted to: $[6 \%$ divided by $(11 \%+6 \%)]=0: 35$ or $35 \%$. Thus, the profitsharing ratio be declared at 65:35. More can be presented the following table:

Table 3: Calculation of Profit-Sharing Ratio on Mudhârabah Time Deposit

\begin{tabular}{|l|l|}
\hline Ratio for Customer & Ratio for Bank \\
\hline $11 \% /(11 \%+6 \%)=0.65(65 \%)$ & $6 \% /(11 \%+6 \%)=0.35(35 \%)$ \\
\hline or & \\
\hline $0.11 /(0.11+0.06)=0.65(65 \%)$ & $0.0 .6 /(0.11+0.06)=0.35(35 \%)$ \\
\hline
\end{tabular}

Source: Indonesia Central Bank (2013), after being reprocessed

\section{Return on Mudhârabah Time Deposit}

How to calculate the profit-sharing on mudhârabah time deposit? The calculation of profit-sharing on mudhârabah time deposit paid at the end of each month with the general ratio, for example $65 \%$ for customer, and $35 \%$ for Islamic bank, can be presented as follows, for example, a customer opens a account of mudhârabah time deposit on August 1, 2014 with a balance of Rp. 250.000 .000 , - within a period of one month. The ratio for the customer is $65 \%$, and 35\% for Islamic bank and the revenues of the Islamic bank in August is Rp. $65,000,000$,- and the average balance of depositor funds on mudhârabah time deposit is Rp. 5,000,000,000,-. The calculation steps of profit-sharing received by the customer can be presented mathematically in the following table: ${ }^{27}$

\section{Table 4: Data for Calculation of Return on Mudhârabah Time Deposit}

\begin{tabular}{|c|c|}
\hline $\begin{array}{l}\text { - } \text { Average Balance of Deposit } \\
\text { - } \\
\text { Average Balance of Deposit on } \\
\text { Depositors } \\
\text { - }\end{array}$ & $\begin{array}{ll}- & \text { Rp. } 250.000 .000,- \\
- & \text { Rp. } 5.000 .000 .000,- \\
- & 65 \%(35 \%) \\
- & \text { Rp. } 65.000 .000,- \\
- & \text { August } 1,2014 \\
- & 31 \text { days }\end{array}$ \\
\hline
\end{tabular}

The data in the table above are used to operate the general calculation formula of profit-sharing on mudhârabah time deposit. The general formula is: (Average Balance of Deposits/Average Balance of Deposit on Depositors) $x$ Ratio $x$ Revenue Shared Out $x$ Number of Days on Revenue/Number of

\footnotetext{
${ }^{27}$ Adiwarman A. Karim, Bank Islam, p. 319.
} 
days in 1 month. ${ }^{28}$ Thus, profit-sharing received by the customer in the month of August 2014 is: $(250,000,000 / 5,000,000,000) \times 0.65 \times 65,000,000 \times 31 / 31=$ Rp. 2,112,500.

In practice, however, people do not need to worry about the results of mathematical calculations as presented above. Just ask the indicative rate of mudhârabah time deposit wanted in the Islamic bank. The indicative rate is equivalent rate value of the investment income will be distributed to the customer, expressed as a percentage, for example $8 \%$ or $11 \%$ or $12 \%$. So that people can quickly and easily calculate the rate of profit to be gained in investing in the Islamic banks, and the level of profits earned guaranteed not to contain elements of usury because it is run in accordance with the shariah of Islam.

Therefore, the customers who open an account of mudhârabah time deposit in the Islamic banks, must not only pay attention to the things mentioned above, but also is required to pay attention to following technical matters. ${ }^{29}$ They are

1. Duration of mudhârabah time deposit, namely: 1, 3, 6, and 12 months.

2. Benefit, namely: Safe and secured by the Deposit Insurance Agency (LPS), competitive profit-sharing, automatically renewable at maturity (ARO), and can be used as financing collateral.

3. Requirements, namely: Filling the account opening form of mudhârabah time deposit, filling and completing the specimen signature card, depositing the initial deposit in accordance with the bank's minimum requirement, and identity card, namely: KTP/SIM/PASSPORT.

4. The rules and rates (rates can be changed according to the decision of ALCO) can be presented in the following table:

Tabel 5: Rule and Rate on Mudhârabah Time Deposit

\begin{tabular}{|l|l|}
\hline \multicolumn{1}{|c|}{ Rule } & \multicolumn{1}{c|}{ Rate } \\
\hline - Minimum Initial Deposit & - Rp. 3.000.000, - \\
- Minimum Deposit & - Rp. 1.000.000, - \\
- Monthly Cost for & - Free \\
Administration & \\
- Administrative Cost for \\
$\begin{array}{l}\text { Disbursement before } \\
\text { Maturity }\end{array}$ & $\begin{array}{l}\text { Rp. 25.000, - at least 3 days after } \\
\text { opening/extension, Rp. 50.000 for } \\
\text { the balance up to Rp. 100 million, }\end{array}$ \\
\hline
\end{tabular}

${ }^{28}$ Ibid., p. 313.

${ }^{29}$ Habib Nazir dan Muhammad Hasanuddin, Ensiklopedia Ekonomi dan Perbankan Syariah (Bandung: Kaki Lima, 2004), p. 132-133. 


\begin{tabular}{|l|l|}
\hline & $\begin{array}{l}\text { Rp. } 100.000 \text { for the balance above } \\
\text { Rp. } 100 \text { million }\end{array}$ \\
- & Rp. $20.000,-$
\end{tabular}

\section{Ilustration of Intersest and Profit-Sharing}

If the conventional banks are offering a fixed deposit rate, for example $6 \%$ multiplied by the amount of money deposited, then the rate on mudharabah time deposit in the Islamic banks is not fixed, because it depends on the magnitude of the gains obtained by the Islamic bank within a specified period. In addition, the interest on time deposits in conventional banks is set fixed, meaning that any state-financed bank customer's business, the customer must pay interest amounting to $\mathrm{X} \%$. Similarly, the bank, whatever the circumstances, the bank must pay interest to depositors by $\mathrm{X} \%$. There are no fluctuating variables such as profit-sharing system, for example in Indonesia Muamalat Bank, it is simplified in the formula: $\mathrm{Hi}=1000 .^{30}$ Another Islamic banks also have a respective calculation formula for the mudhârabah time deposit.

The Illustrations of profit-sharing for the time deposits can be presented as follows, for example: A customer has a 1-month mudhârabah time deposit in Indonesia Muamalat Bank, Rp. 100 million and also Rp 100 million in BNI Bank. The formula for the calculation of the profit-sharing used is the formula used in Indonesia Muamalat Bank. This calculation is done globally to facilitate the understanding of the working pattern for profit-sharing in Indonesia Muamalat Bank. With formula Hi-1000 = Rp. 10.93 or return on investment per Rp. 1,000 of customer fund is $\mathrm{Rp} .10 .93$. Thus the customer is entitled to the proceeds of Rp.546,500. How to calculate it?

Hi-1000 is the index value of each bank profit for Rp. 1,000 fund invested every month. For example, Hi-1000 in August 2014 was 8.5, meaning of each Rp.1.000 generates a profit of Rp. 8.5. Thus, Hi-1000=Rp. 10.93 is the bank generates net profit of management per Rp. 1,000 of customer's fund. Its value fluctuates, depending on many things, but the main thing is the condition of business which is financed by Indonesia Muamalat Bank. The calculation can be presented as follows, for example: Ratio for proft-sharing to 1 month time deposit $=50: 50(50 \%$ for the customer, $50 \%$ for the bank), then the calculation is obtained as follows: $(\mathbf{R p . 1 0 0 , 0 0 0 , 0 0 0 / R p . 1 , 0 0 0}) \times(R p .10 .93 \times \mathbf{5 0 \%})=\mathbf{R p}$. 546,500. In another month, if Hi-1000 is not as big as it was, profit-sharing for the customer also is not as big as it is, and vice versa. Thus, if the average customer's business which is financed by Indonesia Muamalat Bank is good, the level of profit to be obtained will also be good, and vice versa.

${ }^{30}$ Albertus Lalaun, Analisis Perhitungan Bagi Hasil yang Diterima oleh Nasabah pada PT. Bank Muamalah Cabang Ambon, p. 441. 
What about the interest on time deposits in conventional banks? The Illustration of the calculation of interest on time deposits in conventional banks uses the general calculation formula of interest on time deposits. If so, then the customer will receive interest, Rp. 452,054. How could this happen? 1 month time deposit rate $=5.5 \%$ per year (example of BNI Bank in September 2014). The calculation result obtained is: $(\mathbf{R p . 1 0 0 , 0 0 0 , 0 0 0} \times 30$ days) $\times(\mathbf{5 . 5 \%}$ / 365 days) $=$ Rp. 452,054.

From the above it can be concluded that the size of the income earned by depositors in Islamic banks relies on revenue of bank, profit-sharing between bank and customer, time deposit nominal of customer, and average of time deposit for the same period in the bank, whereas in conventional banks will depend on the prevailing interest rate, time deposit nominal of customer, and term of deposit. Basically, Islamic banks provide profit to the depositors with the approach of Financing to Deposit Ration (FDR), while conventional banks with the cost approach. This means that in recognizing revenue, Islamic banks weigh ratio of third-party funds and financing facilities, as well as revenue generated from a combination of these two factors. While conventional banks immediately assume all of the interest that is given is the cost, regardless of how much revenue is generated from the collected funds. ${ }^{31}$

Although such calculations above illustration shows that the return of time deposits received by depositors in Islamic banks is greater than the return of the deposits received by depositors in conventional banks, namely $\mathrm{Rp}$. 546,500 compared to Rp. 452,054, but there is uncertainty in Islamic banks in obtaining the profit, because how many rupiahs of real income to be earned by customers relies heavily on the income of banks. ${ }^{32}$ It means that profit-sharing system in Islamic banks contains a high risk because it depends on the condition of the bank, and banks rely on customer condition financed. If the customer's business which is financed by Islamic bank advanced, the Islamic bank will also be developed, and depositor will also obtain a greater return, and vice versa. This means that the return of time deposit received by mudhârabah time depositor is indefinite, while the return of time deposit in conventional banks is definite, therefore almost no risk. If so, the public will become more interested in depositing their money in conventional banks than in Islamic banks, because they will get a definite profit every month from the bank without any risk bears.

\section{E. Competitiveness of Return on Mudhârabah Time Deposit}

Although the profit-sharing system implemented in Islamic banks contain a high risk, but the return of mudhârabah time deposits in Islamic banks

\footnotetext{
${ }^{31}$ Muhammad, Manajemen Bank Syariah, p. 144.

${ }^{32}$ Ibid.
} 
can still compete with the return of time deposits in conventional banks. There are two main aspects that can be done to optimize the competitiveness of return on mudhârabah time deposits in Islamic banks, namely: the aspect of profit and non-profit. From the aspect of profit, the way which can be done according Muhammad are: (1) providing subsidies to depositors if the profit given to is smaller when compared to the prevailing interest rate, and (2) providing a special ratio to depositors. ${ }^{33}$

The illustration given by Muhammad, associated with both methods may be presented as follows, for example, it is assumed at the end of each month (as of August 31, 2014) the average of financing is Rp. 600 Million, the average of depositor fund is Rp. 475 million, income of the debtor is Rp. 28 million, profit-sharing of debtor Rp. 39 Million. How much income will be distributed to the depositor? The answer is: (Rp. 475 million/Rp. 600 million) $\mathrm{x}$ Rp. (39-28) million $=$ Rp. 8,708,333. The number of Rp. 8,708,333 is the total income of the bank, and to remain competitive with conventional banks, according to Muhammad Islamic banks can provide a special ratio to depositors, namely by reducing the portion of the bank or increase the cost for profitsharing of third-party funds. Therefore, to provide pricing on product liability should be noticed: (1) profit-sharing ratio, (2) quality, (3) income and (4) the average of specific products. ${ }^{34}$

In practice, Islamic banks set the rate of the profit-sharing ratio varies depending on the length of time period, for example in Indonesia Muamalah Bank: the profit-sharing ratio of 1 month is 50: 50, 2 months is 50.5: 49.5, 3 months is $51: 49,6$ months is $52: 48$, and 12 months is 54: 46. In addition, it also offers a special ratio, i.e. the rate of ratio negotiated with the bank if the limitation fund deposited is mininmal Rp.100 million, e.g. 75\% for customer, even higher than that, depending on the amount of money deposited and economic conditions. ${ }^{35}$

In addition ratio, Indonesia Muamalat Bank also offers to depositors to choose kind of profit, namely capitalizing profit and profit transfer. Capitalizing profit is the amount of profit that is combined with the rate of the initial deposit to be deposited in the next time period, while the profit transfer is the amount of profit per period is transferred to a Muamalat saving account. It will be more profitable if it is capitalized because the profit will be doubled, in conventional bank it is called compound interest. Its illustration can be presented as follows, for example: A customer deposits at Indonesia Muamalat Bank on Septermber 2014 worth of Rp 10 million. A period of one month with a ratio of 50: 50. Hi-

${ }^{33} \mathrm{Ibid}$.

${ }^{34}$ Ibid., p. 144-145.

${ }^{35}$ Albertus Lalaun, Analisis Perhitungan Bagi Hasil yang Diterima oleh Nasabah pada PT. Bank Muamalah Cabang Ambon, p. 457. 
1000 in Septermber 2014 is 9.5. The value of profit-sharing for customer is $($ Deposit Value $/ 1000) \times(\mathrm{Hi}-1000) \times(\%$ ratio $)=(10$ million/1000 $) \times 9.5 \times$ $(50 / 100)=$ Rp. 47,500 . If the customer automatically renews and capitalizes it, Hi-1000 in October 2014 is 10.5, then the value of profit-sharing for customer is $($ Deposit Value + Profit-Sharing in October $/ 1000) \times($ Hi-1000 $) \times(\%$ ratio $)=$ $((10$ Million $+47,500) / 1000) \times 10.5 \times(50 / 100)=$ Rp. $52,749.38 .^{36}$

Nevertheless, the calculation mechanism as illustrated above, according to Albertus Lalaun, is still closed, not trasparent so that the public (depositors) has do not know the mechanism, including the profit to be distributed to depositors themselves. Therefore, The Islamic bank should be more transparent in any profits will be given to each of its depositors. ${ }^{37}$

To solve this problem, the non-profit aspect in efforts to increase competitiveness of return on mudhârabah time deposits as previously mentioned needs to be realized by the Islamic banks, because a cooperation based on mudhârabah contract is a partnership full of confidence that the bank as a party was given the mandate to manage the business required to emulate nature of Rasullullah's "STAF", namely: Shiddîq, Tablîg, 'Amânah, and Fathanah. Attitude and behavior of the bank should be Shiddîq (true, honest), Tablîg (communicative, openness, transparency), 'Amânah (responsibility, trustworthy, credibility) and Fathânah (smart, thoughtful, intellectual) in managing the funds of the depositors. ${ }^{38}$ This is a non-profit aspect in question. Without being based on non-profit aspect of this, there is no justice and transparency between the banks and their depositors, especially with regard to the distribution of profits which are the main characteristics of Islamic banks.

Thus, mudhârabah time deposits can still be profitable and provide a fair share of profits to all parties involved, namely the depositor and the bank. The profit is obtained not by interest calculated on the balance of deposits, but the percent of real income of bank and depositors. The revenue of bank is recognized when the profit-sharing received (cash based) rather than interest accrued (accrual based). Islamic Banking Statistics data show that FDR of Islamic banks is always above $100 \% .{ }^{39}$ This means that all third party funds distributed to the public, no one played on derivative transactions, as is the case today in the convensional banks. Time deposit products offered by Islamic banks also help the planning of the public investment, so that the financial

${ }^{36}$ Ibid., p. 455.

${ }^{37}$ Ibid., p. 439.

${ }^{38}$ Muhammad Syafi'i Antonio, Ensiklopedia Leadership \& Management Muhammad saw. Super Leader Super Manager: Bisnis dan Kewirausahaan (Bogor: Tazkiah Publishing, 2010), p. 62-67.

${ }^{39}$ Indonesia Financial Services Authority (OJK), Indonesia Banking Statistics, Montly Journal (ISSN: 2086-2954), Vol. 12 No. 12 November 2014, p. 38-39. 
planning is a necessity in today. One interesting alternative to invest is to place the funds for investment in Islamic banks through the time deposit product.

\section{F. Conclution}

From a series of the above discussion, the conclusion that can be drawn in this study are as follows: Basically, Islamic banks provide profit to the depositor with the approach of Financing to Deposit Ration (FDR), which is in recognizing revenue, Islamic banks weigh ratio of third-party funds and financing facilities, as well as revenue generated from a combination of these two factors. Therefore, the size of the return on deposits granted to depositors of Islamic banks is calculated based on bank earnings, profit-sharing between banks and depositors, time deposit nominal for depositors, and the average of deposit for the same period in the bank.

Return on deposits that are distributed to depositors in Islamic banks is not based on interest calculated on the balance of deposits, but based on the percent of real income of bank and depositors. The revenue of bank is recognized when the profit-sharing received (cash based) rather than interest accrued (accrual based). It means that mudhârabah time deposits can still be profitable and provide a fair return to all parties involved, namely the depositors and the bank without leaving any shariah elements. 
Optimizing The Competitiveness of Return on Mudhârabah Time Deposit in Improving Public Interest to Invest in Islamic Bank

\section{REFERENCES}

Al-Harram, Saad Abdul Sattar, 1996, Islamic Finance: Partnership Financing, Malaysia: Pelanduk Publications.

Antonio, Muhammad Syafi'i, 2010, Ensiklopedia Leadership \& Management Muhammad saw. Super Leader Super Manager: Bisnis dan Kewirausahaan, Bogor: Tazkiah Publishing.

Ascarya, 2007, Akad dan Produk Bank Syariah, Jakarta: RajaGrafindo.

Departemen Agama RI, 2003, Al-Qur'an dan Terjemahnya, Bandung: CV Penerbit Diponegoro.

Dewan Syariah Nasional MUI, 2000, Fatwa DSN MUI Tentang Deposito, No.: 03/DSN-MUI/IV.

Direktorat Perbankan Syariah Bank Indonesia, 2013, Menghitung Bagi Hasil iB, Dokumen Internal, No. 13.

Indonesia Financial Services Authority (OJK) 2014, Indonesia Banking Statistics, Montly Journal (ISSN: 2086-2954), Vol. 12 No. 12 November.

Indonesia Financial Services Authority (OJK), 2014, Islamic Banking Statistics, Montly Journal (ISSN: 2086-2953), Vol. 11 No. 11.

Jones, Charles P., 1996, Investments: Analysis and Management, New York, John Wiley \& Sons Inc.

Karim, Adiwarman A., 2007, Bank Islam: Analisis Fiqih dan Keuangan, Jakarta: RajaGrafindo.

Kholis, Nur, dkk., 2012, Pengantar Ekonomi Islam, Yogyakarta: Kopertais Wilayah III UIN Sunan Kalijaga Yogyakarta.

Lalaun, Albertus, 2014, Analisis Perhitungan Bagi Hasil yang Diterima oleh Nasabah pada PT. Bank Muamalah Cabang Ambon, Jurnal Sosial Keagamaan Inferensi, Vol. 8 No.2.

Muhammad, 2005, Manajemen Bank Syariah: Edisi Revisi, Yogyakart: UPP AMP YKPN.

Nazir, Habib dan Hasanuddin, Muhammad, 2004, Ensiklopedia Ekonomi dan Perbankan Syariah, Bandung: Kaki Lima.

Rivai, Veithzal, dkk., 2007, Bank and Financial Management, Jakarta: RajaGrafindo. 


\section{Syaparuddin}

Undang-Undang Republik Indonesia No. 21 Tahun 2008 tentang Perbankan Syariah pada Bab I Pasal 1 Ayat 22.

Usman, Rahmadi, 2005, Produk dan Akad Perbankan Syariah di Indonesia, Bandung: Citra Aditya Bakti.

Wiroso, 2005, Penghimpunan Dana dan Distribusi Hasil Usaha Bank Syariah, Jakarta: Grasindo. 